\title{
The Economic and Social Impact of Transnational Crime in Pattaya City, Thailand
}

\section{Pornthep Namakorn}

\author{
Graduate School of Public Administration, Burapha University, Thailand
}

\begin{abstract}
This research aimed to study (1) the characteristics, types or forms of transnational crime in Pattaya City; (2) to study contextrelated transnational crime, and (3) to study the economic and social impact on Pattaya City of transnational crime. The populations of this study were divided into 2 groups: the people who lived in Pattaya City and the government officials who were working in this area. The sample size was 400 and was selected by random sampling. The research used both quantitative and qualitative research. For quantitative research, data were collected by questionnaires and were analyzed by frequency, percentage, mean and standard deviation. In terms of qualitative research, data were collected by document study and in-depth interviews with key informants and were analyzed by content analysis. The research found that the forms of transnational crime were committed jointly with Thai people and mostly by foreigners. It was found that the nationalities most involved with transnational crime were Russian and Pakistanis and Islamic countries. The nature and types of transnational crime in Pattaya City were illicit trafficking in drugs, trafficking in women, and money laundering. The analysis of characteristics of illicit activities concluded that the key group was the Russians, the Scandinavians, the Chinese, and the Indians. Transnational crime affected both the economy and society of Pattaya City. It mostly affected people's way of life. It could be seen that people not only feared for the safety of their lives and property, but it also affected local traditions. Evidence of the facts impacting society and economy were found as follows: (1) Tradition and culture today are different from what they were in the past. (2) There was wide spread larceny, theft and holdup. (3) The rate of drug addiction was growing.
\end{abstract}

Keywords: Transnational Crime, Economic Impact, Social Impact

\section{Introduction}

In the time of globalization, economic, social and technological change happens quickly. These changes effect global growth because people around the world can connect with each other through unlimited data, and trade. The logistics of goods and product delivery can be achieved in only 5-10 minutes, so the capacity of world trade can achieve a quantum leap in growth when compared with the development of world commerce before. These changes affect the economic systems and global community in both bad and good ways.

On the other hand, illegal world business has developed crime organizations and expanded its networks to engage in criminal activities in every part of the world. These are known as Transnational Crime Organizations. Transnational crime affects the security of nations, so UNESCO has an interest in this problem and has divided transnational crime into 10 characteristics, namely: 1) illicit trafficking in drugs; 2) smuggling of illegal migrants; 3) arms trafficking; 4) trafficking in nuclear material; 5) transnational criminal organization and terrorism; 6) trafficking in women and children; 7) trafficking in body parts; 8) theft and smuggling of vehicles; 9) money laundering, and; 10) other activities.

Thailand is one country where foreigners from around the world can visit and stay easily because of the Thailand's tourism policy which encourages tourism because of the income it generates. In the year 2011, there were 20,468,020 foreigner visits to Thailand (Thailand National Police Institution). Thailand therefore has had to face the risk of transnational crime from these foreign visitors.

Pattaya City is a famous place in eastern Thailand and very well known amongst foreigners. It is not far from Bangkok (about 
140 kilometers) and is only about one and a half hour from Suvarnabhumi Airport by road. Many foreign tourists visit Pattaya City from the Asia Pacific region, such as Japanese and Malaysians; Western tourists, such as the United Kingdom, Australia, Germany, the United States and Scandinavia and; the Middle East and Russia. Pattaya City has the potential for transnational crime as a result of the large number of foreign visitors.

The researcher would therefore like to study the economic and social impacts of transnational crime in Pattaya City. The results of this study can help to protect Thailand from transnational crime more effectively.

\section{Research Objectives and Research Methodology}

\subsection{Research objectives}

2.1.1. To study the characteristics, types or forms of transnational crime in Pattaya City.

2.1.2. To study context-related transnational crime.

2.1.3. To study the economic and social impacts of transnational crime on Pattaya City. his research used mixed methodology with both quantitative and qualitative research being conducted.

\subsection{Research methodology}

\subsubsection{The populations and samples}

1) For quantitative research, the populations of this study were 2 groups: people who lived in Pattaya City and the government officials who were working in this area. The samples were divided into 2 groups: 300 people who lived in Pattaya City, and 100 government officials who were working in this area. The samples were selected by random sampling.

2) For qualitative research, the key informants of this study were 2 groups: 7 people who lived in Pattaya City, and 8 government officials who were working in this area. The key informants were selected by purposive sampling.

2.2.2. The instruments

This research used two instruments.

1) For quantitative research, data were collected by questionnaires. This questionnaire was to study the opinion of people and government officials who lived and were working in Pattaya City about; the characteristics, types or forms of transnational crime in Pattaya City, context-related transnational crime, and the economic and social impacts of transnational crime on Pattaya City.

2) For qualitative research, data were collected by in-depth interviews from key informants. This question was to ask the opinion of key informants: people and government officials about; the characteristics, types or forms of transnational crime in Pattaya City, context-related transnational crime, and the economic and social impacts of transnational crime on Pattaya City.

\subsubsection{Data analysis}

1) The data obtained from the questionnaires were analyzed by frequency, percentage (\%), mean (X), and standard deviation (S.D.).

2) The data obtained from key informants were analyzed by content analysis.

\section{Findings}

3.1. The opinions of people and government officials in Pattaya City agreed in general that transnational crime in Pattaya City was committed jointly by both Thai people and foreigners.

3.2. It was found that the nationalities most involved with transnational crime were Russian and Pakistanis and Islamic countries.

3.3. It was found that the nature and types of transnational crime in Pattaya City were mostly smuggling in particular: Ice was imported from Myanmar, Ecstasy (E) was imported from countries in Europe, and Cocaine was imported from South American countries.

3.4. The characteristics of misconduct by transnational criminals could be divided into groups. The key group was the Russians who owned the entertainment businesses, travel businesses and prostitution services. Second, Scandinavians owned the entertainment businesses and import-export businesses but also smuggled the drugs. Third, the Chinese owned travel businesses but counterfeited government documents and imported Chinese gangs. Finally, Indians owned legal businesses when in fact they counterfeited passports and credit cards including stealing from hotels or shops.

3.5. The overall impact on society, economy and life styles from transnational crime in Pattaya City was at a very serious level. Therefore, transnational crime affects both the economy and society. There was an impact on 
employment and tourism in Pattaya City, because sometimes there was only trade within the same nationality because foreign business people had more capital or better funding, so Thai businesses lost opportunities. Moreover, the public sector, both National and local, had to pay to build public utilities or other costs for which taxes or fees could not be collected because of the illegal nature of the businesses. In addition, Thai social values have changed from the past, because the youth in Pattaya City committed misconduct such as drug dealing and stealing. For example, young women thought that prostitution was normal, lucrative fun and was an effective way to find a foreign husband. In addition, Thai traditions such as Songkran and Loy Kra-tong Festivals were seen as for entertainment only.

\section{Conclusion}

The results of this study revealed that the opinions of the people and government officials in Pattaya City were that transnational crime was committed jointly by both Thai people and foreigners. This is in accordance with the results of Chaisiam (2007), 'Transnational Crime in Thailand and Correction Measurement'. Because of the weakness of Thailand's laws about marriage with foreigners, if these foreigners wanted to run businesses in Pattaya City, they have to marry Thai women. This is one way that transnational crime was committed jointly by both foreigners and Thais in Pattaya City. So the government should improve laws about foreigners' professions in Thailand and laws should be up-to-date on illegal base of transnational crime.

The results of this study revealed that the nationalities most involved with transnational crime were Russians. This is in accordance with the article of Anuchart (2010), 'Russian Organized Crime in Thailand' because Pattaya City has an increasing number of Russian tourists (about 643,070 in 2010), and 'The Department of Homeland Security' reported that Russian crime organization in Pattaya City has conducted transnational crime such as money laundering, drug dealing, investment in real-estate, financial and securities fraud, human trafficking, murder, cyber-crime, and smuggling of stolen vehicles but these the developments have been done in secret. Thai people have not thought about the dangers of transnational crime from Russia, so relevant government officials should be trained to be proficient in their duty.

The overall impact on society, economy and life styles from transnational crime in Pattaya City was at a very serious level. So the civil society and mass media sector should be further encouraged to become involved with transnational crime and prevention to help solve the transnational crime problem and its impacts in Pattaya City more effectively.

\section{References}

[1] Anuchart Boonnak. Russian Organized Crime in Thailand. Retrieved from http://th.anuchart.net/files/RussianOrganization\%20Crime.pdf, 2010.

[2] Chaisiam Yingheng. Transnational Crime in Thailand and Correction Measurement. Bangkok: Krirk University, 2007.

[3] James O.Finckenauer and Ko-Lin Chin. Asian Transnational Organized Crime. Nova Science Pub Inc, 2006.

[4] Sittipong Tanyapongpruch. Transnational Organized Crime in Thailand. Retrieved from

http://www.unafei.or.jp/english/pdf/RS_No 59/No 59_40 PA_Tanyapongpruch.pdf, 2002.

[5] Thomas Schmid. 2010. The Darker Side of Tropical Bliss: Foreign Mafia in Thailand. Retrieved from $\mathrm{http}: / / \mathrm{www}$.thailawforum.com/foreignmafia-thailand.html

[6] Thailand National Police Institution. Statistics: International Arrivals to Thailand Year 2011. Immigration Bureau, Police Department, 2011.

[7] United Nations. Globalization of Crime : A Transnational Organized Crime Threat Assessment. United Nations Publication, 2010. 